\title{
162. Coronarchirurgie im Rahmen einer allgemeinchirurgischen Abteilung
}

P. Brücke

Am Steinbruch 29, A-4040 Linz-Puchenau

\section{Cardiac Surgery in a Department of General Surgery}

Summary. The development of a unit for cardiac surgery within a department of general surgery is discussed. An increase from 26 to over 200 cases within 6 years, with mortality decreasing to $0.8 \%$, seems to justify our next goal, i.e. the establishment of a special department for cardiac surgery.

Key words: Cardiac surgery - Decreasing lethality.

Zusammenfassung. Der Aufbau einer coronarchirurgischen Station an einer Allgemeinchirurgie wird geschildert. Frequenzsteigerung von 26 auf über 200 Fälle in 6 Jahren mit Verbesserung der Resultate und $0.8 \%$ Letalität wird erzielt. Die Errichtung einer Spezialabteilung für Herzchirurgie ist das nächste notwendige Ziel.

Schliisselwörter: Coronarchirurgie - Verbesserung der Letalitätsrate. 